九州大学学術情報リポジトリ

Kyushu University Institutional Repository

\title{
Some Doubtful Cretaceous Ammonite Genera from Japan and Saghalien
}

Wright, Claud William

Matsumoto, Tatsuro

Department of Geology, Faculty of Sciences, Kyushu University

https://doi.org/10.5109/1524111

出版情報：九州大學理學部紀要：Series D, Geology. 4 (2)，pp.107-134，1954-07-31. Faculty of Science, Kyushu University バージョン：

権利関係 : 


\section{Some Doubtful Cretaceous Ammonite Genera from Japan and Saghalien}

By

\section{Claud William WRIGHT}

(London)

and

\section{Tatsuro MATSUMOTO}

(Department of Geology, Kyushu University, Fukuoka)

\section{Introduction}

A considerable number of $\not$ ammonite genera have been proposed in Japan for Cretaceous forms, which for various reasons are of doubtful nomenclatorial validity. One of us (T.M.) hopes eventually to monograph the Cretaceous Ammonites of Hokkaido and Saghalien and is at present engaged in a series of studies of certain ammonite families. He has however joined the other author in the present paper in order that properly established names may meanwhile be available for both stratigraphic and palaeontological purposes.

We endeavour to clear up the nomenclatorial problems raised by these doubtful names but in the process have been compelled to discuss a number of taxonomic questions.

\section{Relevant Clauses of the Rules of Zoological Nomenclature}

Pending the issue of a revised set of the Rules in accordance with the decision of the 1948 and 1953 International Congresses of Zoology, the following Articles 25 is effective:-

"The valid name of a genus or species can only be that name under which it was first designated on the condition:

(a) that (prior to January 1, 1931) this name was published and accompanied by an indication, or a definition, or a description; and

(b) that the author has applied the principles of binary nomenclature.

(c) But no generic name nor specific name, published after December 31, 1930, shall have any status of availability (hence also of validity) under the Rules, unless and until it is published either

(1) with a summary of characters (seu diagnosis; seu definition; seu condensed description) which differentiate or distinguish the genus or the species from other genera or species; 
(2) or with a definite bibliographic reference to such summary of characters (seu diagnosis; seu definition; seu condensed description; and further

(3) in the case of a generic name, with the definite unambiguous designation of the type species (seu genotype; seu autogenotype; seu orthotype).

\section{Alphabetical List of Nomenclatorially Doubtful Nominal Genera and Subgenera of Japanese Cretaceous Ammonites}

\begin{tabular}{|c|c|}
\hline See Page & See Page \\
\hline Anagaudryceras SHIMIZU, 1934, $1935 \ldots \ldots .112$ & Neodesmoceras MATsumoto, 1947 \\
\hline Anapuzosia MATsumoto, 1938.............124 & Neoepigoniceras SHIMIzU, $1935 \ldots . .$. \\
\hline Anazelandites MATSUMото, $1938 \ldots \ldots$ & Neogaudryceras SHIMIZU, $1934 \ldots$ \\
\hline Damesites MATsumoto, $1942 \ldots \ldots \ldots$ & Neoturrilites SHIMIZU, 1935 \\
\hline Eoepigoniceras SHIMIZU, $1935 \ldots \ldots \ldots \ldots \ldots 110$ & Neophylloceras SHIMizU, 1934 \\
\hline Eogunnarites MATSUMOTo, 1942 ..........125 & Neopuzosia MAтsumoto, 1954 ... \\
\hline Eomadrasites MATsumoTo, 1954. & Orientoceras SHIMIZU, 1935 \\
\hline Epigaudryceras SHIMIZU, $1934 \ldots \ldots \ldots \ldots 112$ & Paragaudryceras SHIMIzU, 1934 \\
\hline Epipachydiscus YABE and SHIMIzU, 1926125 & Paraphylloceras SHIMizU, 1934 ... \\
\hline Euhyphantoceras SHIMIZU, 1935 & Pseudogaudryceras SHIMIzU, 1934 \\
\hline Hemigaudryceras SHIMIZU, 1934 & Pseudoxybeloceras MATsumo Го, 1938. \\
\hline Hypogaudryceras SHIMIZU, 1934 ..........111 & Reesidites MATsumoto, $1942 \ldots .$. \\
\hline Hypoturrilites SHIMIzU, 1935 .......... & Rotalinites SHIMIZU, $1935 \ldots \ldots \ldots \ldots$ \\
\hline Jacobitoides MATSUMOTo, $1954 \ldots \ldots$ & Ryugasella MAtsumoto, 1942 .. \\
\hline Jimboiceras SHIMIZU, 1935. & Saghalinites SHIMIzU, $1935 . . . . .$. \\
\hline Kossmatia YАBE, 1927 & Scalarites MATsumoto, $1838 \ldots .$. \\
\hline Kotoceras YABE, 1927 & Spathinella SHIMIZU, 1935 \\
\hline Marshallites MatsumoTo, $1954 \quad \ldots \ldots \ldots \ldots .125$ & Subprionocyclus SнImızU, $1932 .$. \\
\hline Mesopuzosia MATsUMoтo, $1938 \ldots$ & Yokoyamaoceras SHIMIZU, $1935 .$. \\
\hline
\end{tabular}

Family Phylloceratidae ZitTEL

Shimizu has proposed two genera for late Upper Cretaceous Phylloceratidae, Neophylloceras in 1934 (p. 61, in SHImizu \& OватA) and Paraphylloceras (1935b, p. 180). In 1934 he stated that "Neophylloceras gen. nov. must be separated from Phylloceras Suess em. SpATH on account of the considerable difference in suture-line" (translation from Japanese). He designated $P$. ramosum (MEeK) as the type species and set out in a table (table 11, p. 61) the difference between Neophylloceras and Phylloceras, as follows: 


\section{"Phylloceras}

Incision of suture line simple

External and two lateral saddles are shallowly bipartite; the subdivisions of the saddles are rounded and phylloid

Lobes are broad, tripartite and a little asymmetric

\section{Neophylloceras}

Incision of suture line complicated

External and two lateral saddles are deeply bipartite and the subdivisions are again bipartite

Lobes are narrow, tripartite and much more asymmetric than in Phylloceras; the outer branch being much better developed than the inner"

Thus Neophylloceras is valid from 1934. However, the publication was in Japanese in a book which had a small circulation and it has been largely ignored.

SHimizu added at that time that "The so-called Phylloceras ramosum in Japan must be called Neophylloceras subramosum sp. nov. because of the considerable difference from the type of $N$. ramosum (MEEK)." Unfortunately this new species was left undescribed although a good illustration was given (fig. 34 A, B, C, p. 62). Curiously Shimizu in 1935 appeared to ignore his Neophylloceras, including only as apparent misprints in lists "Neophylloceras aff. velledae" (p. 193) and "Phylloceras subramosum gen. et sp. nov." (p. 171); on p. 177 he remarked that Phylloceras velledae of Yokoyama (1890) seemed to be identical with his P. subramosum.

Spatil (1939) pointed out the confusion in Shimizu's 1935 paper and, after examining a specimen in the British Museum labelled "Neophylloceras subramosum Shimizu" by Shimizu himself, accepted the taxonomic necessity of the genus and designated as type species $N$. subramosum SHimizu. He gave a definition of this species and, although he suggested that despite the absence of a description by SHImizu the 1935 reference to a good figure by $\mathrm{YABE}_{\mathrm{ABE}}$ (1927) might serve to validate the species, we feel that the species can only validly date from SpAтн's 1939 description.

As indicated above however and despite Spath's recent statement to the contrary (1953, p. 6) Neophylloceras Shimizu, 1934 is valid and its type species is Ammonites (Scaphites ?) ramosus MEEK, 1857.

Paraphylloceras was not mentioned by SHimizu in 1934 but was proposed in 1935b (p. 180) as follows:- " Paraphylloceras gen. nov. is proposed for the group of Phylloceras surya Forbes and selected $P$. costatum sp. nov. as its genotype. The ornamentation of Paraphylloceras is of a special type. Phylloceras radiatum MARshal. may belong to this stock. This also includes Paraphy. marshalli nom. nov. (=Phylloc. nera Marshalr. (non Forees))." As Spath (1939) pointed out P. costatum is a nomen nudum and surya would have to be the type of the genus.

However Paraphylloceras SHimizu, 1935 is a stillborn homonym of Paraphylloceras SAlfeld, 1919. Spath (1953, p. 4) argues that since Paraphylloceras SAlfeld is an objective synonym of Parapsiloceras Hyaт, 1900 it was stillborn and does not in- 
validate Paraphylloceras SHImizu. However this situation would only arise if Paraphylloceras SALfeld were a homonym, which it is not. Thus not only is Paraphylloceras SHimizu invalid but the name could only be used for the group for which Parapsiloceras HYAтT is in fact the correct name.

The question remains whether the group of Phylloceras surya (Forbes) needs to be separated from Neophylloceras. Matsumoto (1942e, p. 675) suggested that "the more remarkably costate forms like "Phylloceras surya (ForBEs) may be treated as a subgenus" of Neophylloceras. Spath also (1953) maintains the genus. On the other hand in those genera of Phylloceratidae characterised by strong ornament, the ribs vary much in strength and in stage at which they occur, both within and between species, as indeed is well shown in certain species of the surya group. Our present view is that separation of the surya group is not taxonomically necessary.

\section{Family Tetragonitidae Spath}

Shimizu (1935b) set up three new genera, Eoepigoniceras, Neoepigoniceras and Saghalinites, in this family, all of which are invalid for want of differentiation or description. Moreover one of them, Neoepigoniceras, had a type species which was invalid for the same reason. Only one of the three names, Saghalinites is, we believe, taxonomically required.

\section{Epigoniceras Spath, 1925}

Type species: Tetragonites epigonum Kossmat, 1895.

Differs from its ancestor Tetragonites, which it otherwise closely resembles, in having a distinctly recurved suspensive lobe.

E. (Epigoniceras) (includes Eoepigoniceras, Neoepigoniceras SHıмıU, 1935 nomina nuda)

Moderately involute. Combines Epigoniceras type of suture with oval, subquadrate or trapezoidal whorl section, as in Tetragonites. Ranges from Turonian to Maestrichtian.

The designated type species of Eoepigoniceras, Tetragonites kingianus Kossmat, only differs from contemporary and later members of the subgenus it its oval whorl section, an unimportant feature. Neoepigoniceras was based on N. schmidti, a nomen nudum, being founded without description on figures in ScHMIDT, 1873, which in fact reveal no differences sufficient to justify even subgeneric separation of the form.

E. (Saghalinites), subgen. nov.

(ex Shimizu, 1935b, p. 181)

Type species: Ammonites cala Forbes, 1846.

Very evolute and widely umbilicate, the whorl height increasing slowly. 
Whorl section rounded or octagonal.

Shimizu designated as type species of his genus Saghalinites " S. saghalinensis nov." which he differentiated from $A$. cala FoRBes sufficiently to validate the specific name, but since saghalinensis has never been figured and no holotype was mentioned, we prefer, in validating the genus, to choose as type the well known species of Forbes. Spath $(1953$, p. 8) used Saghalinites as a genus but did not validate it.

The genus ranges from Campanian* to Maestrichtian.

\section{Family Gaudryceratidae SpaTH}

Shimizu (in Shimizu \& Obata, 1934 and Shimizu 1935a, b) set up a number of genera or subgenera in this family of doubtful validity; there were moreover differences in treatment between the 1934 and 1935 papers. Spath (1953) has recently reviewed some of these genera.

Hypogaudryceras Shimizu, 1934 was established with " $H$. compressum Shimizu" as designated type species. This species however was neither described nor illustrated, either in 1929 when it was first mentioned or in 1934 or 1935, and the genus was not defined. In 1934 SHimizu merely remarked that "Hypogaudryceras and varunaites** resemble each other and are grouped into the subfamily Hypogaudryceratinae SHIMIzU. The diagnosis of the subfamily is in its compressed, smooth whorls" (translation from Japanese). He listed Hypogaudryceras kawanoi (JiMBo) as another member of the genus. In 1935b (p. 179) he remarked that "Hypogaudryceras subgen. nov." was created by himself "for the group of Lytoceras (Gaudryceras) dozei FALLoT and $G$. (H.) compressum Shimizu from the Upper Albian of South Saghalien taken as its genotype." On the same page Shimizu referred Desmoceras kawanoi Jimbo to Zelandites MARShall (misprinted Zealandites) with a query and suggested that Lytoceras (Gaudryceras) odiense Kossmat from the Utatur Group of South India might belong to Hypogaudryceras. H. compressum remained a nomen nudum and the difference between Hypogaudryceras and Zelandites ("Varunaites") were not stated.

Hypogaudryceras might be validated by selecting ${ }_{8}$ Ammonites dozei Fallot as type. This species has been described by JacoB (1907) and Pervinouière (1910). Matsumoto (1938b) has referred it doubtfully to Zelandites, with the remark that it is not typical as it has a moderately wide umbilicus, rounded umbilical edge and almost symmetrical first lateral lobe. However most immature Zelandites are less involute than adult specimens. Supposedly adult $G$. dozei figured by Pervinquière

* S. cf. cala (ForBEs) was once recorded from the Japanese Neourakawan (T. M. 1942d, p. 673). As a result of the recent knowledge of the correlation between Hokkaido and Kii (Wakayama Prefecture) the age must be changed to the Paleohetonaian. i. e. Campanian.

** Varunaites SHIMIZU, 1926 (type species Am. varuna ForbEs) is a synonym (see MATsuMOTO, 1938) of Zelandites MARShALL, 1926, as apparently recognized by SHIMIZU in 1935. 
has an umbilicus $34 \%$ of the diameter, as in adult G. Alicki Pervinquière, compared with $30.3 \%$ in Zelandites mihoensis Matsumoro. Such differences are not more than specific.

In our opinion all the species mentioned can be safely referred at present to Zelandites, the genus comprising small, compressed, involute gaudryceratids, with fairly narrow umbilicus and a first lateral lobe of varying degrees of asymmetry. Although its range, Albian to Maestrichtian, is rather long, as in the case of Anagaudryceras mentioned below, we hesitate to establish divisions until more convincing evidence is obtained. Similarly we regard as unnecessary the subgenus Anazelandites MAtsumoto, 1938b suggested provisionally for G. flicki Pervinquitère.

Anagaudryceras was proposed by Shimizu in 1934 (in Shimizu \& Oвата, p. 67) and Ammonites sacya Forbes was designated as type species. SHimizu gave no generic diagnosis but said that the genus corresponded to what $\mathrm{Y}_{\mathrm{ABE}}(1903, \mathrm{p}$. 17) called the group of Gaudryceras sacya (FonEEs). This may be regarded as satisfying Article 25 (c) (2) and the genus is thus valid.

Similarly the following genera proposed by SHimizu in 1934 might be regarded as nomenclatorially valid on the basis of their correspondance to YABE's groups :-

Shimizu's proposals

Neogaudryceras SHIMIZU

type species $N$. tenuiliratum (Y $\mathrm{YBE}$ )

Epigaudryceras SHimizu

type species $E$. striatum (JiMBo)

Paragaudryceras SHIMIZU

type species $P$. limatum ( $\mathrm{YABE}$ )

Hemigaudryceras SHIMIZU

type species $H$. denmanense (WHITEAvEs)
YABE's corresponding groups

Group of G. tenuiliratum Y $\mathrm{ABE}$

, $\quad$ G. crassicostatum (Jimbo)

", G. limatum $\mathrm{Y}_{\mathrm{ABE}}$

, , G. denmanense (WhItEAves)

In the same work Shimizu set up Pseudogaudryceras, without description, with type species $P$. infrequens (YABE) ( $=$ Gaudryceras tenuiliratum var. infrequens $\mathrm{Y}_{\mathrm{ABE}}$, 1903).

In a work (1935a) slightly earlier than his main paper of that year SHIMIzU referred to Anagaudryceras as "subgen. nov." and designated another species as type, G. (A.) utaturense sp. nov. (=Ammonites sacya STOLICZKA, 1865 non Forbes, 1846). Later in 1935b Shimizu abandoned Epigaudryceras as a synonym of Neogaudryceras and treated the remainder of his 1934 genera as subgenera of Gaudryceras.

Spath in 1953 referred only to Shimizu's illegitimate 1935 designation of StoLICZKA's “Am. sacya" (non Forbes) as type species of Anagaudryceras, adopted Neogaudryceras and commented on the other subgenera, without settling their validity or otherwise. 
Now YABE's subdivision of Gaudryceras was based primarily on the characters, especially the often coarse ribbing, of the last whorl. This ribbing however is very variable within and between species both as regards its form and the stage of growth at which it appears; it forms no reliable basis for generic classification. Matsumoto (1942c) has shown that two well defined groups can be distinguished, Gaudryceras sensu stricto, characterised by fine but strong, very sigmoidal riblets with a forward projection on the periphery, and Anagaudryceras with still finer and much weaker ornament, sometimes so fine as to be imperceptible to the naked eye, which though oblique on the umbilical wall is not markedly sinuous on the sides or shoulders.*

The only obvious character of G. tenuiliratum $\mathrm{Y}_{\mathrm{ABE}}$, the type of Neogaudryceras Shimizu, that is not mentioned above is the branching of the riblets, as in the later Vertebrites, during mid growth, but this feature occurs to a variable extent in both Gaudryceras and Anagaudryceras. Indeed YABE placed G. mite (designated as type species of Gaudryceras by Boule, Lemoine \& Thévenin in 1906) in his group of $G$. tenuiliratum.

G. limatum YABE belongs to Anagaudryceras and Paragaudryceras is therefore a synonym of that genus. $G$. denmanense, the type of Hemigaudryceras and $G$. intermedium, the type of Pseudogaudryceras, are typical members of Gaudryceras sensu stricto.

Thus we have the following synonymies:-

Anagaudryceras SHimizu, 1934

=Paragaudryceras SHimizU, 1934

Gaudryceras DE GROSSOUVRE, 1894

=Epigaudryceras, Hemigaudryceras, Neogaudryceras, Pseudogaudryceras

SHIMIZU, 1934

Zelandites MARShat.L, 1926

=Varunaites Shimizu, 1926; Hypogaudryceras Shimizu, 1934; Anazelandites Matsumoto, 1938.

Family Turrilitidae MEeK

SHimizu (1935b, p. 195) proposed without any description the nominal genus Hypoturrilites "for Turrilites komatai (YABE)" (recte komotai $\mathrm{Y}_{\mathrm{ABE}}$ ) and stated that “Turrilites gravesianus d'ORBIGNY and T. tuberculatus Bosc in d'ORBIGNY may belong to this genus".

The fact that this genus, though never defined, has been used several times in

* Although the holotype of $A$. sacya (FORBES) (BM. 10486) is a poorly preserved immature specimen, it does show the typical characters given above. The generic definition is not affected whatever is the answer to the question whether or not Am. buddha FoRBEs is a fragment of an adult of the same species. 
the literature suggests that it is taxonomically necessary and it has now been validated by Dubourdieu (1953), with Turrilites gravesianus d'Orbigny as type species.

\section{Family Nostoceratidae HyATT}

A number of new generic names that are invalid or doubtful have been set up for some of the rich fauna of heteromorphs from the Cretaceous of Japan and Saghalien. However there is difficulty in stabilising the nomenclature in the absence of a secure taxonomic arrangement of the post-Cenomanian uncoiled forms. Their classification must therefore be discussed here.

HyatT (1900) set up Hyphantoceras for the European Turonian species reussianum d'ORBIGNY, previously referred to Heteroceras, a Barremian genus. H. reussianum is characterised by irregular helical coiling, typically with retroversal Ushaped body chamber, round whorl section, weak to moderately strong annular ribs and periodic thin tuberculate flares and an ornate lytoceratoid suture; the earlier whorls are sometimes but by no means always rather regularly in contact but the later ones form a very open and variable spiral. There are usually also referred to Hyphantoceras a number of Turonian to Santonian turreted forms whose whorls are in contact until the latest stage when there is an uncoiled or even U-shaped body chamber. Some of these species have marked constrictions sometimes with a projecting rib behind, while others have none. They are all more properly to be referred to Bostrychoceras Hyatт.

Amongst the variable forms of these genera can be seen the probable origins of nearly all the Turonian and later heteromorphs of both the Nostoceratidae and the Diplomoceratidae. SPAтн $(1953$, p. 16, 17) has suggested six subfamilies for the Nostoceratidae. While some subdivision of the family may prove necessary, there is too little knowledge at present to justify it, certainly on such a scale.

Against this background we can review the genera now in question.

Orientoceras was set up by Shimizu (1935b, p. 198) for Heteroceras orientale $\mathrm{Y}_{\mathrm{ABE}}, 1904$. No description was given; it was merely suggested that $H$. oshimai YABE (pars, pl. iii, fig. 6, non fig. 5) might be the young stage of $H$. orientale. In fact both orientale and oshimai, with irregular helicoid coiling and fine simple ribs with periodical elevated tuberculated ones, fall within Hyphantoceras as defined above.

Euhyphantoceras was set up by Shimizu (1935b, p. 181) as follows:-“" for $E$. maestrichtiense nom. nov. (=Helicoceras venustum $\mathrm{YABE}$, loc. cit., (1904), Pl. V, figs. 1, 2 non Pl. III, fig. 4) as its genotype. The holotype of this genus coils loosely and is provided with alternately tuberculate and plain costation; tuberculate ribs disappear at about the middle of the flanks from where usually 2 or 3 plain ribs originate. 
This genus differs from Hyphantoceras not only in its crioceratid coiling but more significantly in the ornamentation."

The specimen referred to by SHimizu has been examined by one of us (T.M.). As indeed the figure suggests, its ornament is not as described by SHimizu. Moreover its age is Santonian and not Maestrichtian. More complete specimens of this species show open but distinctly helicoid whorls in the early stages and the species is clearly a Hyphantoceras, close indeed to the type species $H$. reussianum. The only difference, a minor one, is that the Santonian form has widely open, low helical coiling at a relatively early stage and constantly fine subcostae between the quadituberculate flared ribs. Forms occur in the Turonian of the Japanese province, and $\mathrm{Y}_{\mathrm{ABE}}$ 's other figured specimen of Helicoceras (?) venustum is one of them, which appears to belong to a bituberculate species of Hyphantoceras; in view of SHimizu's establishment of the species maesirichtiense, the original of YABE'S Pl. III, fig. 4 becomes the holotype of venustum.

The Santonian species has in addition to Shimizu's name maestrichtiense received the name serpentinum Matsumoto (1938a, 1942b p. 161 and elsewhere) (sub Bostry. choceras) but no description was given and the name is invalid. Although SHimizu's name is inappropriate for a Santonian form it cannot under the Rules be rejected on that account. On the other hand his statement about the character of the species is so much at variance with the figure and specimen as to indicate that a mistake has been made.

Neoturrilites was set up by ShimizU (1935b, p. 180) as follows:- "with N. karafutoense sp. nov. as its genotype. The holotype of this species is characterised in having oblique ribs provided with three rows of weak tubercles." Not only is there no generic diagnosis but the description of the type species is quite insufficient for recognition. Both species and genus must be ignored.

Family Diplomoceratidae Spath

For a series of Turonian and Coniacian forms of the Japanese province similar in some respects to Hyphantoceras but with rather different ornament and coiling Matsumoto has used the generic name Scalarites nom. nud. (1938a, p. 193 and passim). These forms are of importance as linking Nostoceratidae to Diplomoceratidae and we validate the genus here.

Scalarites, gen. nov.

(ex Matsumoto, 1938 MS. nom. nud.)

Type species: Helicoceras scalare $\mathrm{YABE}, 1904$.

Diagnosis :-A very shallow, open helicoid spire in the early stages is sooner or later followed by loose elliptical coiling in nearly one plane. The whorls enlarge 

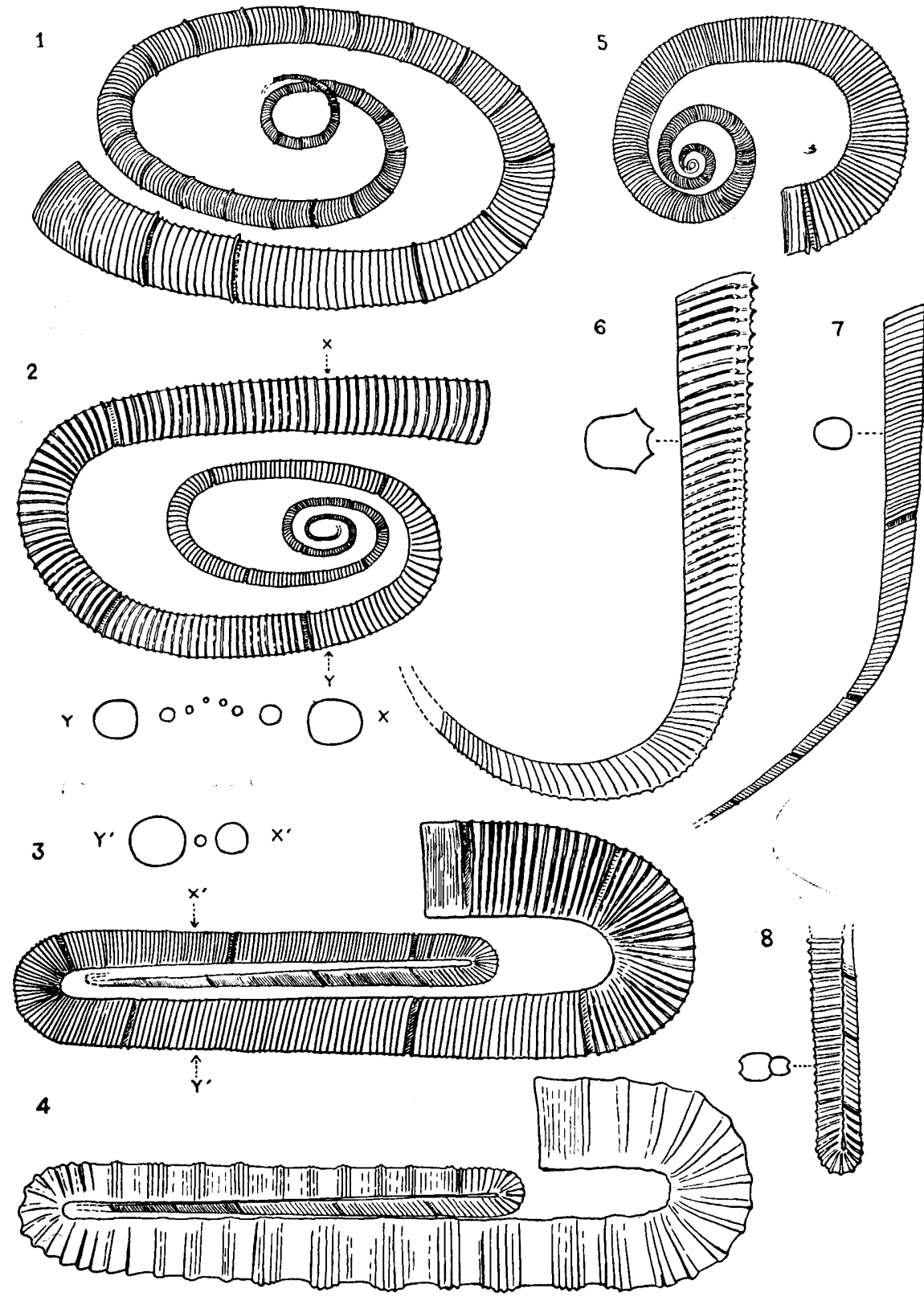

T.M. del.

Figs. 1-8. Diagrammatic figures of some Diplomoceratidae.

1. Scalarites scalaris (YABE) $\left(\times \frac{1}{2}\right)$ Turonian. 2. S. mihoensis sp. nov. ( $\left.\times \frac{1}{2}\right)$ Upper TuronianConiacian. 3. Polyptychoceras obstrictum (JIMво) $\left(\times \frac{1}{2}\right)$ Coniacian.Santonian. 4. Subptychoceras yubarense (Y $\mathrm{ABE})\left(\times \frac{1}{2}\right)$ Santonian. 5. Glyptoxoceras sp., based on BM. 10500, G. rugatum (FORBES) in Kossmat, 1895 ( $\left.\times \frac{2}{3}\right)$ Upper Senonian. 6. Pseudoxybeloceras quadrinodosum (JrMBo) $\left(\times \frac{2}{3}\right)$ Santonian-Campanian. 7. Ryugasella ryugasensis sp. nov. $\left(\times \frac{2}{3}\right)$ Upper Santonian-Campanian. 8. Solenoceras texanum STEPHENSON $(\times 1)$ Campanian. 
very slowly and are more or less circular in section. Ribs simple and annular. Typically there are periodic untuberculated flared ribs or infrequent constrictions. Suture of IULE pattern, all elements bifid except for trifid internal lobe. Remarks:-As the text figures and plate show the genus differs from Hyphantoceras and Bostrychoceras principally in having shallower and still more open coiling, which tends to be elliptical, and in the absence of a retroversal body chamber. It is a relatively small step on the one hand to the Santonian and perhaps Coniacian Polyptychoceras obstrictum (JIMво)* (text fig. 3) and thence to Subptychoceras yubarense (Y $\mathrm{ABE}$ ) (text-fig. 4) and on the other to Glyptoxoceras, including such Indopacific species as $G$. rugatum (ForBEs) (text fig. 5) or G. tenuisulcatum (Forbes). Indeed fragments from the English Coniacian of what are probably a species of Scalarites have been reported as Glyptoxoceras (WRIGHT \& WRIGHT, 1942) and are indistinguishable, so far as they are preserved, from Campanian forms of that genus. Both Glyptoxoceras and Diplomoceras retain the helical coiling of the early whorls and it is therefore reasonable that Scalarites should be associated with them in the family Diplomoceratidae.

\section{Scalarites scalaris (YABE)}

\section{P1. 7, fig. 3; Text fig. 1}

1894. Hamites sp., JıмBo, p. 40, pl. ix, fig. 1 ; pl. vii, fig. 7, 7 a.

1904. Helicoceras scalare YABE, p. 9, pl, iii, figs. 2, 3a-c.

Types: YABE's syntypes are Nos. GT.I-233** and GT.I-234a,b from the “Scaphites beds" of the Opirashibets, Teshio Province, Hokkaido. Jimвo's specimens from the Opirashibets are also referable to the present species. In subsequent collections there are number of specimens, though more or less frag. mentary: e.g. GT.I-2930a, b-GT.I-2937 from the zone Mh2 of the Miho group in the Naibuchi Valley, South Saghalien; GT. I-3350 and GT. I-3361 from the Saku formation in the Saku-Abeshinai area, Teshio Province, Hokkaido; GK.H1441GK. H1443 from the Saku formation in the Shiyubari Valley, Ishikari Province, Hokkaido (all coll. by T. M.).

Diagnosis: Very low, rather variable helical coils in the early stages, followed by later whorls of loose and broadly elliptical coiling with nearly U-shaped bends. Section subcircular in earlier whorls and elliptical and compressed with rather flattened flanks in later whorls. Prominent annular periodic ribs, frequent and

* This species has been erroneously referred to Diplomoceras. JimBo's type species, as well as others, has a straight first arm between but not in contact with the second and the third ones. It has not yet been found in the Maestrichtian in the Japanese province but is characteristic to the Urakawan, i.e. Santonian plus Coniacian.

*k The following symbols are used in the register numbers of Japanese specimens. GT. Geological Institute, University of Tokyo and GK. Department of Geology, Kyushu University, Fukuoka. 
fairly regular in most whorls but infrequent in the late part, with numerous annular ribs of moderate strength bitween them.

Remarks: YABE's original specimens are fragments of early and middle-aged whorls. The better one (GT.I-233) shows a nearly spiral coil with the curvature slightly different at places and is not strictly in one plane. In subsequent collections there are several specimens which correspond in age with YABE's. They show more distinctly the variable curvature and the irregularly helicoid coiling. The fragments of larger whorls with heights from $10 \mathrm{~mm}$ to $25 \mathrm{~mm}$ indicate a very gently arcuate long arm and strongly curved almost U-shapped short part. The largest fragment, a little over $25 \mathrm{~mm}$. in whorl-height, is moderately curved and shows densely crowded striae. The reconstructed shell-form is shown diagrammatically in text fig. 1, although no perfect specimen has yet been collected. The ornament was correctly described by $\mathrm{YABE}$ but the periodic strong ribs become infrequent and rather irregular in spacing on the last whorl.

Occurrence: Neogyliakian, approximately Turonian, in Hokkaido and South Saghalien, especially common in its lower part.

\section{Scalarites mihoensis, sp. nov.}

P1. 7, figs. 1, 2; Text fig. 2

Holotype: GT. I-295la (immature) from loc. N27a, zone Mh4 of the Miho group in the Naibuchi Valley, South Saghalien (coll. T. M.).

Paratypes: GT. I-2951b, I-2949, I-2950, I-2953-I-2956 from the zones Mh3 and Mh4 in the Naibuchi Valley; GT. I-3352, I-3354, I-3357, I-3362, I-3363, I-3373, I3375, I-3382, I-3383 from beds IId and IIIa in the Abeshinai Valley, Teshio Proviñce, Hokkaido; GK. H1451 and GK.H1454 from beds IIs and IIIa in the Shiyubari Valley, Ishikari Province, Hokkaido. Comparable specimens have been found at corresponding horizons in other areas of Hokkaido.

Diagnosis: Coiling elliptical and loose in early stages and elongated elliptical with nearly straight arms and moderately curved parts in later stages; whorls separated but only slightly so in the straightened part of the later whorls. Section subcircular in early whorls and somewhat flattened dorsally in the last whorl, height and breadth much the same. Very infrequent periodic strong ribs and occasional constrictions. Numerous, narrow, annular ribs of considerable elevation, separated by broader interspaces.

Remarks: This species is interesting in that its coiling is more elliptical than that of the preceding species. The flared ribs become more infrequent, while constrictions are occasionally found. All these features seem to indicate a progression from the typical Scalarites scalaris to Polyptychoceras, but the species must still be referred to Scalarites. 
Besides the illustrated specimens there are a number among which some are fairly large with a nearly straight arm of $20 \mathrm{~cm}$. in length and whorl-height of about $30 \mathrm{~mm}$.

Occurrence: Upper part of the Neogyliakian and Paleourakawan in South Saghalien and Hokkaido, approximately Upper Turonian and Coniacian.

Besides the above two species we have recognized at least two other species referable to Scalarites. One has a similar mode of coiling to that of $\boldsymbol{S}$. scalaris and very frequent periodic flared ribs with intervening faint striae or weak subcostae. It seems to be confined to the lower part of the Neogyliakian. The other has straighter arms than $S$. mihoensis and dense ribs of moderate strength. It is closely allied to Polyptychoceras obstrictum (JimBo) and occurs in the Paleourakawan and the uppermost part of the Neogyliakian.

As explained above Scalarites may be derived from Hyphantoceras, or from some common ancestor of Hyphantoceras and Bostrychoceras, and in turns leads to the group of the Upper Cretaceous forms, Polyptychoceras Y $\mathrm{ABE}, 1927$ and Subptychoceras Shimizu, 1935c, for which, and also for Scalarites itself, the family Polyptychoceratidae Matsumoto (1938a, p. 193) was established. The North American group of Solenoceras (and Oxybeloceras if distinct) may be bituberculate derivatives of Polyptychoceras or possibly independent offshoots of some later Nostoceratid of Emperoceras type. The family includes also a few forms whose names require to be stabilized.

Pseudoxybeloceras, gen. nov.

(ex MAtsumoto, 1938, MS. nom. nud.)

Type species: Hamites quadrinodosus Jімво, 1894.

Diagnosis: Shell in one plane, arcuate at first, then moderately curved, finally straight, thus forming a J. Whorl section more or less compressed. Simple, fine, rather prorsiradiate ribs with upper or upper and lower ventro-lateral spines. Suture IULE, with all elements bifid and more or less equal except for I which is small and trifid.

Remarks : In its ornament Pseudoxybeloceras resembles some species of Solenoceras (cf. STEphenson, 1941) but this genus is distinguished by its tight ptychoceratid coiling. It might be suggested that the affinities of the present genus lie with the Turonian and possibly Coniacian Allocrioceras SpATH, which already has a pair of ventral tubercles. On the other hand, just as Solenoceras may be a tuberculate descendant of Polyptychoceras, so Pseudoxybeloceras is taken to be a tuberculate and straightening offshoot of Scalarites.

The J-shaped coiling of the preserved fragments and the four rows of tubercles recall the group of 'Ancyloceras' pseudoarmatum Schlüter (1871-6, pp. 99 and 164, pl. xxxi, figs. 1-3; pl. xliii, figs. 5-9). That species however and the 
closely allied 'Ancyloceras' kossmati Simionescu (1899, p. 21, pl. 1, figs. 6, 7, 8a, b) are characterised by more or less inflated, instead of flattened, whorl section and periodic strong tuberculate ribs with weaker intermediate ones which may or may not have tubercles; moreover the ribs are often doubled, as in Anisoceras, between the tubercles. Spatr (1921, p. 52) stated the 'Ancyloceras' pseudoar. matum ScH. ÜTER probably represented an adult whorl fragment of a species of his new genus Neocrioceras, of which only the helically coiled early whorls were then known. The largest specimen certainly attributed to Neocrioceras (an example of $N$. spinigerum figured by Shimizu, 1933, pl. ii, figs. 4-9) tends to support Spath's view. 'Oxybeloceras' sanushibense YABE MS. is described and figures below for purpose of comparison with Pseudoxybeloceras.

Range: Pseudoxybeloceras is not uncommon in the Upper Santonian and Campanian of Japanese province; it occurs in Fondoland* and possibly in New Zealand ${ }^{* *}$.

\section{Pseudoxybeloceras quadrinodosum (JiмBo) \\ Pl. 7, fig. 6a, b; Text figs. 6, 9-12}

1894. Hamites quadrinodosus JimBo, p. 39, pl. vii, figs. 3, 4.

1927. Oxybeloceras quadrinodosum (J1MBO) Y ABE, p. 44 (18).

The early arcuate part is succeeded by a moderately curved and then by a straight part, but it is not yet certain whether the moderate curvature appears

T. M. del.

9A

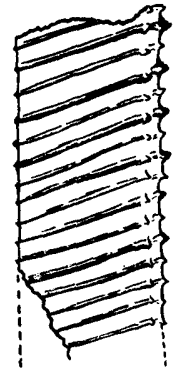

$9 \mathrm{~B}$

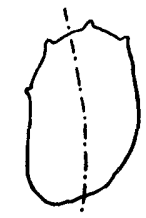

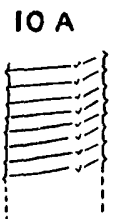

$11 \mathrm{~A}$

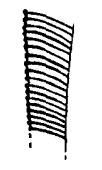

108

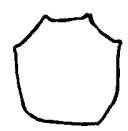

118
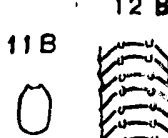

$12 \mathrm{~A}$
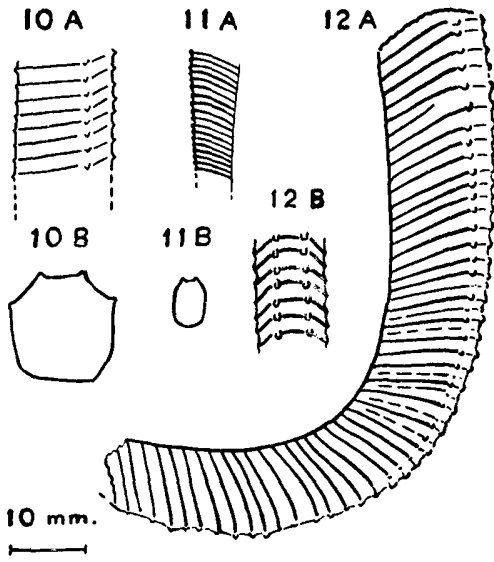

Figs. 9-12. Pseudoxybeloceras quadrinodosum (JімBо)

9 A,B. Lectotype. GT.I-125, lateral view and cross section (deformed). 10 A,B. Syntype. GT.I126a, lateral view and cross section (secondarily depressed). $11 \mathrm{~A}, \mathrm{~B}$. Syntype. GT.I-126b, lateral view and cross section. 12 A,B. YABE's specimen. GT.I-341, lateral and part of ventral views.

* Oxybeloceras (?) cf. quadrinodosum (JIMBO) SPATH, 1921, p. 50, pl. vii, fig. 2a, b; Hamites amapondensis van HoEPEN, 1921, p. 15, pl. iii, figs. 5, 6, text fig. 9 .

** Oxybeloceras sp., Marshall, 1926, p. 156, pl. 33. 
once or twice. The section is fairly compressed at first but only slightly so at a later stage. The siphonal area is somewhat flattened and the shoulders sub. angular or rounded. The ribs are simple, dense, sharp and narrow and are separated by rather broader interspaces; in the early part they are prorsiradiate and distinctly concave on the dorsum but cross the venter transversely; later are less prorsiradiate. Each rib has small spinose tubercles on the shoulders and on either side of the flattened siphonal area. The lower tubercle is at first very indistinct or absent. The tubercles are usually equal until the last part on which strong and weak ones alternate. Occasionally a fine untuberculate rib is intercalated.

Jimвo, who based the species on straight fragments alone, regarded it as Hamites. YABE and SPATH referred it to Oxybeloceras, which has however an arcuate or straight shaft followed by a sharply bent over hook, besides having different ornament (fig. 8).

Occurrence: Besides Jimвo's original material from Chiptanshibets on the Tumbets River, Kitami Province (GT.I-125 \& 126a, b) specimens have subsequently been found from the Anapachydiscus beds in the valley of the Ikushumbets (GT.I-341, coll. YABE), from bed Ur5 in the Urakawa area, Hokkaido (GK. H3543) and from zones Mh6 and Ray ${ }_{1}$ in South Saghalien (GT. I-2859 and 2860, coll. T. M.). All these occurrences are in the Santonian and Campanian.

Neocrioceras (?) sanushibense, sp. nov.

(ex YABE, 1901 MS. nom. nud.)

Pl. 7, fig. $5 \mathrm{a}, \mathrm{b}$; Text fig. 22 .

1909. Hamites sanushibensis $\mathrm{YABE}$, p. 440 , listed.

1927. Oxybeloceras sanushibense $\mathrm{Y}_{\mathrm{ABE}}$, p. 44 (18), listed.

The holotype is YABE's original specimen (GT.I-340) from the "Pachydiscus" (Anapachydiscus) Bed at locality "B" on the Saushisanushibe, Iburi Province, Hokkaido. The paratype is GK. H3542 (T. M. coll.) from bed Ur5 $\beta$ at locality U238, Urakawa area, Hokkaido.

The fragmentary holotype is more or less J-shaped but the paratype shows again a curved part at a still later growth-stage. The whorl section is subcircular and as high as broad. The numerous annular ribs are only slightly oblique on the straight limb. Every fourth or fifth rib is stronger in the outer part and likewise has stronger ventrolateral and ventral tubercles than the other, narrow and sharp ribs. Sometimes two or three of the minor ribs are united at one of the strong ventrolateral tubercles.

This species is obviously allied to 'Ancyloceras' pseudoarmatum ScHLüTER and ' $A$.' kossmati Simionescu. It is distinguished from both these species by its 
subangulate ventrolateral shoulders and the ventrolateral, instead of mediolateral, position of the lower tubercles.

This species is somewhat allied to but readily distinguished, together with the above two species, from Pseudoxybeloceras by their subcircular or oval whorl section, radial ribs, periodic strong ribs which have strong tubercles and a tendency to double or treble the ribs between the tubercles, while they are similar to the type species of Neocrioceras in most of these characters except for the depressed whorl section of that species.

Occurrence: The species has been found in the upper part of the Urakawan and the lower part of the Hetonaian, that is in the Upper Santonian and Campanian.

\section{Ryugasella, gen. nov.}

(ex Matsumoto, 1942 MS. nom. nud., as subgenus of Pseudoxybeloceras)

Type species: Ryugasella ryugasensis, sp. nov.

Diagnosis: In one plane, broadly curved at an early stage then sooner or later becoming quite straight, the resulting shape being that of the Japanese long sword "naginata". The form of the earliest growth stage is still uncertain. Section oval to circular. The ribs are dense, annular, prorsiradiate and untuberculate. There are occasional constrictions. Suture IULE, with all the elements bifid except for trifid I.

Remarks: The genus is similar in general aspect to Pseudoxybeloceras but differs in coiling, circular section and in the absence of tubercles. It may well be another offshoot of late Scalarites.

Range: The occurrence is almost the same as that of Pseudoxybeloceras, namely Campanian and perhaps late Santonian of the Japanese province and perhaps the Campanian of Graham Land*.

Ryugasella ryugasensis, sp. nov.

(ex Matsumoto, 1938 MS. nom. nud.)

P1. 7, fig. 4a-d; Text figs. 7, 13A-E

? 1890. Anisoceras cfr. rugatum (Forbes) Yokoyama, p. 183, pl. xx, fig. 8.

? 1894. Hamites sp. JiмBo, p. 39, pl. vii, figs. 5, 5a.

1938. Glyptoxoceras (?) ryugasense MATSUMoto, p. 193, listed.

1942. Pseudoxybeloceras (Ryugasella) ryugasense MATSUMoto, p. 167 and elsewhere, listed.

The holotype is GT. I-2862 from loc. N18f, horizon Ray1 in the Naibuchi Valley, South Saghalien (Coll. T. M.).

* Polyptychoceras sp. from Graham Land (SPATH 1953, p. 18, pl. vii, figs. 5a, b, c=BM.C41390 and $\mathrm{C} 41486$ ) is another fragmentary example of this genus, being quite similar to the type species. 
The shell form given in the generic diagnosis is the most probable reconstruction from a number of straight or gently curved fragments. The ribs are sharp and narrow, separated by broader interspaces, and of uniform strength. They are prorsiradiate on the sides but cross the venter transversely. Constrictions are sometimes present especially on the early stages.

Besides the holotype the following material is known:-

GT. I-2861, 2863, 2865 from the Naibuchi Valley, South Saghalien.

GT. I-3587-3589 from the Abeshinai Valley, Teshio Province, Hokkaido.

? GT. I-127 from Opirashibets, Teshio Province (the original of Jimbo, 1834, pl. vii, fig. 5 ).

GK. H3547--3551 from localities in the Urakawa Area, Hokkaido.

These specimens are mostly from the Paleohetonaian, that is Campanian, and a few from the Upper Neourakawan, perhaps the top of the Santonian.

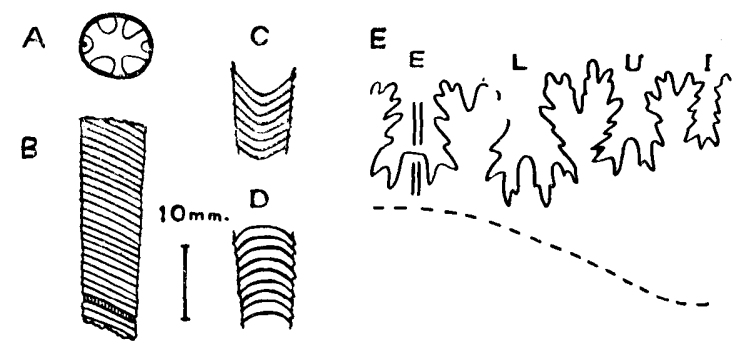

T. M. del.

Fig. 13. Ryugasella ryugasensis sp. nov.

A. Section. B. Lateral view. C. Dorsal view. D. Ventral view.

E. Suture at a whorl-height of $8 \mathrm{~mm}$.

Family Desmoceratidae ZitTer.

Kotoceras appears without diagnosis in a work of YABE's published in 1927, as follows :-

on p. 36 “"Desmoceras” (Kotoceras, YABE, MS.) damesi JIMBO

on p. 44 "Desmoceras (Kotôceras ${ }^{*}$ ) damesi JiMBO

$\begin{array}{lll}" & (\quad) \text { laeve } \mathrm{YABE}^{*} \\ " & (\quad, \quad) \text { semicostatum } \mathrm{Y}_{\mathrm{ABE}}(* \text { MS. nom. })\end{array}$

on explanation of plate VII, fig. $9 a, b$

' Kotôceras (gen. nov.) damesi'

In view of the date of publication (before 31 December 1930) Kotoceras is not necessarily invalid because of lack of description. One valid species, damesi Jimbo, is mentioned and that becomes type species by monotypy.

Kotoceras KoBAYAshi, 1934 is therefore a homonym of Kotoceras YABE, 1927 but 
the latter has already been replaced by Damesites MAtsumoto, 1912a (p. 24) on the grounds that KoBAYASH's name is valid.

It would appear that greater confusion is likely to be caused by maintaining Kotoceras $\mathrm{Y}_{\mathrm{ABE}}$ and consequently an application will be made to the International Commission on Zoological Nomenclature to reject Kotoceras $\mathrm{Y}_{\mathrm{ABE}}$ and uphold Kotoceras Kobayashi and Damesites Matsumoto.

\section{Family Puzosiidae Spath}

(We are are not decided whether this group should be accorded family status or be regarded as a subfamily of Desmoceratidae. The question is not discussed here.)

The following genera or subgenera proposed in this family are invalid for want of description:-

$$
\begin{aligned}
& \text { Anapuzosia Matsumoto, } 1938 \\
& \text { Jimboiceras Shimizu, } 1935 \\
& \text { Mesopuzosia Matsumoto, } 1938 \\
& \text { Neopuzosia MAтsumoto, } 1954
\end{aligned}
$$

These are being dealt with in a forthcoming paper by one of us (T. M.) on the Puzosiidae of Hokkaido and Saghalien and are therefore not treated here.

\section{Family Pachydiscidae Spath}

Shimizu (1935b, p. 181) set up a genus Rotalinites in the following terms: "Menuites rotalinoides (YABE) is quite different from the earlier Ammonites rotalinus SroliczKa, which has a row of tubercles on the venter; this makes it necessary to separate as a new genus Rotalinites gen. nov. (genotype Am. rotalinus SToliczkA)."

'This statement does indicate, though not very clearly, the character of Rotalinites and the genus could be accepted as valid.

The tuberculation of Ammonites rotalinus however is similar to that of Pseudojacobites SpATH, 1926, based on a species of which only one very badly preserved specimen is known. Both Amm. rotalinus and Pseudojacobites farmeryi ( $\mathrm{C}_{\mathrm{RICK}}$ ) may be derived from Lewesiceras, species of which often exhibit strengthening of the ribs on the shoulders and the midline of the venter, where Pseudojacobites has its characteristic tubercles. Although the ribbing of Am. rotalinus differs considerably from that of $P$. farmeryi, we believe that it should, provisionally at any rate, be included in Pseudojacobites, of which Rotalinites Shimizu thus becomes a synonym.

As recently pointed out by Matsumoto \& SAIto (1954) Neodesmoceras was validly described with a valid type species, N. japonicum, by Matsumoto in 1947. However the description was in Japanese. In 1951 (p. 24) Matsumoto gave a résumé in English of his 1947 paper but referred to Neodesmoceras as "subgen. nov." (of 
Pachydiscus) and to its type species as “ $P$. (N.) japonicus SAIto MS," although both subgeneric and specific names had been validly established by himself.

Unfortunately it was only the second paper (1951) that was noticed in other countries and Collignon, for example, (1952) tried unnecessarily to validate Neodesmoceras by designating as its type species Pachydiscus catharinae ANDERSON \& HANNA, 1938, which had been referred to Neodesmoceras with some doubt by MATsuмото.

Epipachydiscus was proposed as a subgenus of Parapachydiscus HYATT by YABE \& Shimizu, 1926 (p. 173), who gave a concise subgeneric diagnosis as follows. "Shell like Parapachydiscus s.s., HYAтT, in form and sculpture. Suture-lines: external part as in Pseudopachydiscus, ${ }^{*}$ but with $\mathrm{l}_{1} \mathrm{I}_{2} \mathrm{l}_{3}$ (i. e. three pairs of internal lobes on both sides of the antisiphonal lobe) erect." However the designated type species, Parapachydiscus mamiyai YABE \& SHIMIzU, and another species doubtfully referred to the subgenus, $P$. abeshinaiensis $\mathrm{YABE}$, have never been described and are therefore invalid. Thus the subgeneric name also is a nomen nudum. Matsumoto $(1947,1951)$ recognized no essential criterion in the character of internal lobes when he treated the Japanese Pachydiscids and failed to find a form which could validate Epipachy. discus with the diagnosis above cited.

\section{Family Kossmaticeratidae SpATH}

This family was established for a group of Senonian derivatives of Puzosiidae, characterized by dense ribbing, tuberculation, constrictions that are oblique to and truncate the ribs and a suture that somewhat resembles that of Puzosiidae. There are however a number of earlier forms mostly from the Indo-Pacific area, ranging from the Upper Albian to the Cenomanian, mainly undescribed, which are morphologically similar to the typical Kossmaticeratidae and are also clearly derived from Puzosiidae. It is by no means clear whether the two groups represent two or more parallel offshoots of different Puzosiidae. The point is not discussed in detail here and the early forms are provisionally included in Kossmaticeratidae.

Two nominal genera have been listed but not fully described; they are validated below. Three other listed genera, Eomadrasites, Jacobitoides and Marshallites Matsuмото, 1954, will be described fully in a forthcoming paper by one of us (T.M.) on the Kossmaticeratidae from Hokkaido and Saghalien and are therefore not dealt with here.

Eogunnarites, gen. nov.

(ex MAtsumoto, 1942 MS. nom. nud.)

Type species: Olcostephanus unicus YABE, 1904.

Diagnosis: Whorl section inflated and depressed. Umbilicus rather narrow or

* Now a synonym of Canadoceras (see MATSUmoto, 1947; 1951). 
of moderate width and rather deep. Umbilical wall steep with subangular umbilical shoulder, ornamented with tubercles. Fine, sharp ribs, slightly convex forwards, rise in bundles from the umbilical tubercles or are intercalated. Regular well marked constrictions each truncate two or three ribs. Suture apparently similar to that of Kossmaticeras (s.s.), comprising the following lobes I, U1, U3 (=S), U4, U2, L, E. L is subsymmetrically trifid. The auxiliaries form a descending series.

Remarks: The holotype of $E$. unicus is rather poorly preserved but subsequent collecting (by T. M.) has furnished several good specimens which confirm the necessity of establishing a new genus. Eogunnarites is distinguished from other members of the family by its whorl section or by its ornamentation. From Fagesia, of Vascoceratidae, which it somewhat resembles in whorl section, it is distinguished by its finer ribs with regular constrictions and especially by its suture, which has the complication characteristic of most Kossmaticeratidae instead of the comparative simplicity of a degenerative acanthoceratid type.

Range: The type species is known from the upper half of the Neomiyakoan and the Paleogyliakian, that is the Upper Albian and Cenomanian.

\section{Eogunnarites unicus (YABE)}

P1. 8, figs. 2a-c; 3a, b; 4a-c; 5a, b; Text figs. $14-20$

1904. Olcostephanus unicus YABE, p. 28, pl. vi, figs. 5a, b.

1925. Fagesia unica (YABE) Diener, Foss. Catal., Ammonoidea Neocretacea, p. 182.

In the earliest stages the whorl section is depressed and lunate. It increases gradually in height and becomes round. The fourth whorl is still smooth, merely with weak constrictions. From a diameter of about $5 \mathrm{~mm}$. the whorl becomes much depressed with broadly arched venter and angular umbilical shoulder. The umbilicus is fairly narrow and very deep. This stage is characterised by umbilical tubercles and geniculate constrictions. At a diameter of about $10 \mathrm{~mm}$. many weak radial subcostae appear near the umbilical tubercles; they are absent on the venter where the constriction curves gently forward.

In the middle growth stages numerous regular sharp subcostae spring in bundles of three or four from each umbilical tubercle. The adult whorl has a more rounded shoulders but is still broader than high. Here two or three additional ribs are intercalated between each bundle. The ribs are nearly straight and radial while the constrictions cut two or three of them.

The suture is in the early stages of development similar to that of young Desmoceras. In the adult it is finely and deeply incised with gradually descending auxiliaries. The formula is $\mathrm{I}, \mathrm{U} 1, \mathrm{U} 3(=\mathrm{S}), \mathrm{U} 4, \mathrm{U} 2, \mathrm{~L}, \mathrm{E} . \mathrm{L}$ is subsymmetric- 
ally trifid and as deep as E. The saddles are bifid. That between U2 and U4 is brord and situated at the umbilical shoulder.
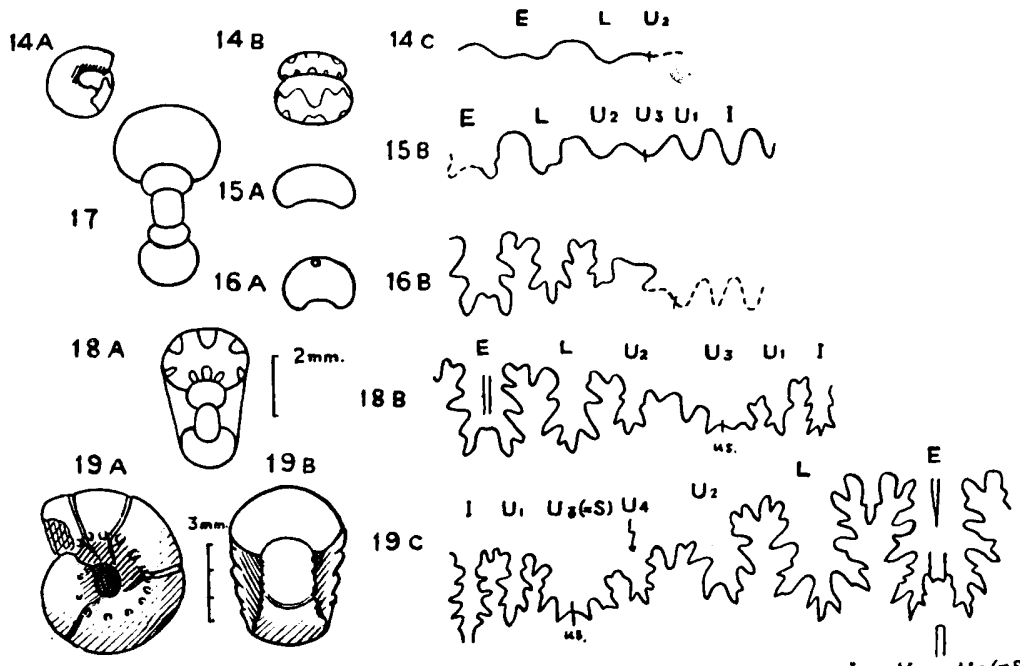

$19 \mathrm{D}$
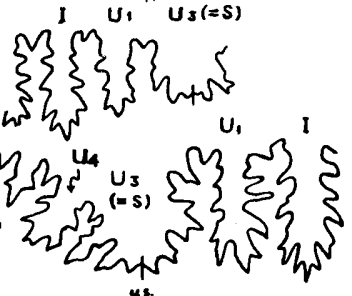

T. M. del.

Figs. 14-20. Eogunnarites unicus (YABE), immature, showing the ontogenetic development. GT. I3246 from locality T591d, horizon lowest Ilb, Middle Yezo Group in the Abeshinai Valley, Teshio Province, Hokkaido. Paleogyliakian (Cenomanian).

$14 \mathrm{~A}, \mathrm{~B}$. The first whorl with the protoconch and the first suture. $15 \mathrm{~A}, \mathrm{~B}$. Section and suture of the second whorl. $16 \mathrm{~A}, \mathrm{~B}$. Section and suture of the early part of the third whorl. 17. Sections up to the late third whorl. $18 \mathrm{~A}, \mathrm{~B}$. Section at a diameter of $4.3 \mathrm{~mm}$. and the suture at a diameter of $2.5 \mathrm{~mm}$. $19 \mathrm{~A}, \mathrm{~B}, \mathrm{C}, \mathrm{D}$. Lateral and apertural views at a diameter of $6.6 \mathrm{~mm}$. and sutures. 20 A, B, C. Lateral and apertural views at a diameter of $11 \mathrm{~mm}$. and the suture.

Measurements :

\begin{tabular}{|c|c|c|c|c|}
\hline \multirow[t]{2}{*}{ Specimen } & Diameter & Height & Breadth & Umbilicus \\
\hline & 4.3 & 1.7 & 2.7 & $1.0(23 \%)$ \\
\hline \multirow[t]{2}{*}{ GT. I-3246 } & 6.6 & 3.4 & 4.8 & $1.5(23 \%)$ \\
\hline & 10.5 & 4.4 & 7.5 & $3.2(30 \%)$ \\
\hline GT. I-3245a & 31.5 & 12.3 & 16.8 & $9.4(29.5 \%)$ \\
\hline GK. H 1556 & & 40.3 & 44.0 & \\
\hline
\end{tabular}

Material: YABE's original specimen, the holotype (GT.I-255), came from near Poronai, Ishikari Province, Hokkaido, probably from the Mikasa ("Trigonia") Sandstone. In addition there are:- 
GT. I-3245a and b bed IIb, Abeshinai Valley, Teshio Province.

GK. H1556-1557 bed IId. Middle Yezo Group, Shiyubari Valley, Ishikari Province.

GT. I-3714 horizon Ky (or possibly Kx), Imano-sawa River, Naibuchi Valley, South Saghalien (T. M. coll.).

In S. NaGao \& A. Osanai Coll. (Sapporo), locality 58, Oyubari area, Ishikari Province.

Fagesia siskiyouensis Anderson (1931, p. 125, pl. 17, figs. 2, 3) from the Middle Chico Group, Turonian (? Upper), of California, rcsembles the adult of the present species at least superficially. It differs in the absence of well marked constrictions and in having rather prorsiradiate ribs. Unfortunately its suture has not been figured.

Shimizu (1935b, p. 198) proposed a genus Yokoyamaoceras "for Holcodiscus kotoi Jімво (genotype Holcodiscus kotoi JIMBO)." No description was given and the name is therefore a nomen mudum. However the group of $H$. kotoi is of some taxonomic importance and we therefore validate the name here.

Yokoyamaoceras, gen. nov.

(ex Shimizu, 1935 nom. nud.)

Type species: Holcodiscus kotoi Jıмво, 1894, p. 33, pl. v (xxi), figs. 2, 2a, 2b.

Diagnosis : Rather small, evolute with compressed whorls. Constrictions frequent, well marked, prorsiradiate on the sides and showing a conspicuous peripheral projection. Ribs numerous, flexuous on the sides and nearly obsolete, in middle growth, on the venter, with or without elevation on the venter in the adult. Ventrolateral tubarcles develop in middle age, but typically there are no umbilical tubercles, apart from an occasional slight elevation just behind a constriction. Apertural margin with moderately projected lappets and rostrum. Suture similar to that of other kossmaticeratids, with trifid $\mathrm{L}$ narrower than $\mathrm{E}$.

Remarks: Yokoyamaoceras resembles the rather earlier Holcodiscoides Spath, 1922 but is distinguished by the general absence of umbilical tubercles. It also resembles the inner whorls of certain contemporary puzosiids ("Kitchinites" japonicus SpATH and "Desmoceras" ishikawai Jimbo) but these do not develop such a flattened venter or such distinct ventrolateral tubercles.

Occurrence: Urakawan, that is Coniacian and Santonian, of the Japanese province and Coniacian or perhaps Turonian of Southern India.

\section{Family Acanthoceratidae DE GrossouvRE}

Kossmatia Y $\mathrm{ABE}, 1927$ (p. 42) non UhL.IG, 1907 was set up without any description in a list. The only species included were pseudodeverianum Jimвo and two nomina

* See also pl. 8, fig. 1a-c of this paper. 
nuda. Fortunately the species pseudodeverianum belongs to Romaniceras SpATH, 1923 , in the synonymy of which Kossmatia Y $\mathrm{ABE}$ falls.

\section{Family Collignoniceratidae (HyAtT) Wright \& Wright}

Shimizu (1932, p. 2) set up a genus Subprionocyclus with type species Prionocyclus hitchinensis Bill.inghurst. He stated that his genus differed from Prionocyclus in ribbing and evolution, but did not specify in what respects, and added that "the siphonal lobe was shorter than the first lateral and the internal suture had a deeply divided external saddle" whereas in Prionocyclus there were two distinct saddles in the internal suture.

The group to which $P$. hitchinensis belongs certainly requires generic separation but Shimizu's description is inadequate.

\section{Subprionocyclus Shimizu, 1932}

Type species: Prionocyclus hitchinensis BILlinghurst, $192 \%$.

Diagnosis : Compressed to quadrate whorled, involute or only moderately evolute. Prominent keel, finely or coarsely serrate. Ribs very fine to rather coarse, sharp at first but may be flattened on later whorls, springing in pairs from faint umbilical bullae or intercalated, usually slightly prorsiradiate and flexuous. Double ventrolateral clavi on all ribs but lower one may be weak on the outer whorls. The ribs always remain regular throughout and never unite at the ventrolateral tubercles.

Remarks: The siphonal lobe is, as Shimizu states, shorter than the first lateral, but so it is in some species at least of true Prionocyclus. His statement about the internal suture is not correct and we find no essential difference in this feature between the two genera (see text fig. 21).

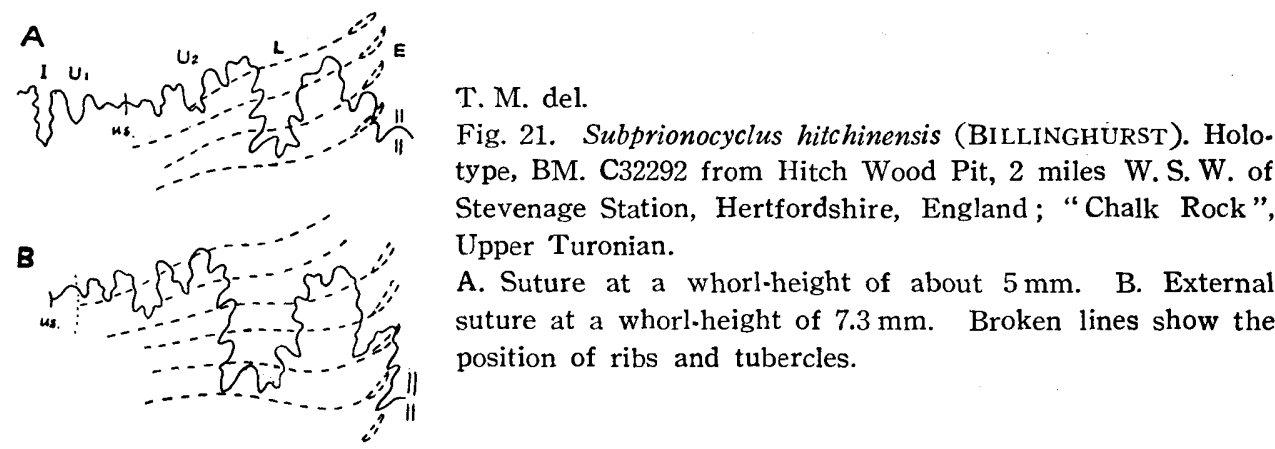

Subprionocyclus includes, besides the type species, the well known Ammonites neptuni Geinitz, the coarsely ribbed Prionotropis cristatus Billinghurst, Schloenbachia knighteni ANDERson (1902, p. 119, pl. i, figs. 1-4; pl. ii, figs. 39-40) and possibly also Schloenbachia siskiyouense ANDERSon (1902, p. 119, pl i, figs. 19-20), 
as well as some undescribed species, including one from Japan. This group is distinguished from Prionocyclus itself by usually greater involution, by the regularity of the ribs, which persists on the outer whorls, and the more clavate ventrolateral tubercles, at which ribs do not unite in pairs. The two genera probably represent parallel and perhaps contemporary offshoots of Collignoniceras. Occurrence: Upper Turonian of Western Europe and the Japanese province and also its presumable equivalent of California.

Subsequently Shimizu (1935b, p. 197) set up a nominal genus as follows:"Spathinella gen. nov. is proposed with $S$. takaoi sp. nov. as its genotype; it differs from Prionocyclus in having wider umbilicus and different ornamentation." This description conveys nothing but in any case the proposed type species is a nomen nudum and the nominal genus Spathinella has no validity.

A species listed, but not described, by $\mathrm{Y}_{\mathrm{ABE}}(1925$, p. 125) as Barroisiceras minimum from the "Scaphites Beds" of Hokkaido, Japan was listed by Matsumoto (1942b, p. 197 and elsewhere) as Reesidites but the genus is a nomen nudum. The species is not a Barroisiceras but is apparently one of the Collignoniceratidae that often resemble Barroisiceras. Although its general form with fastigate and coarsely serrate venter recalls Barroisiceras sensu stricto the sharp forward bend of the ribs, especially on the inner whorls, as they approach the ventrolateral shoulder indicates the connexion with Subprionocyclus. Indeed the ornament of the adult is not unlike that of the outer whorl of Subprionocyclus neptuni (GEINITz), on which the lower ventrolateral tubercle is weak. There are however sufficient differences to justify the validification of Reesidites.

Reesidites, gen. nov.

(ex Matsumoto, 1942 MS. nom. nud.)

Type species: Barroisiceras minimum Hayasaka \& FuKada, 1951

(ex. YABE, 1925 MS nom. nud.).

Diagnosis: Involute, compresed, flat sided with fastigate venter. Sinuous ribs branch in twos or threes from distinct but small umbilical bullae, giving rise to ventrolateral clavi and forming chevrons on the venter; there is a sharp forward bend just below the ventrolateral tubercle. The ribs become increasingly broad and flat with age.

Remarks: The type species, which was fully described by Hayasaka \& FuKada (1951), is the only one so far known. The absence of a lower ventrolateral tubercle at any stage and the strength of the flat ribs on the venter distinguish it from Subprionocyclus. A nearly contemporary genus from South America, Subprionotropis BAsse, 1950, which somewhat resembles Reesidites, differs in being less involute and in having sharper and more distant ribs with subsidiary ventral 
tubercles between the ventrolateral tubercles and the keel. The distinction from Barroisiceras has already been mentioned. The genus is evidently a direct descendant of Subprionocyclus of the neptuni group. A species from the Pacific side of North America, "Schloenbachia" siskiyouense ANDERson, which has been referred to Barroisiceras, seems to represent an intermediate form between the two genera, although it can still be included in Subprionocyclus.

Range: The uppermost part of the Neogyliakian, probably Uppermost Turonian but possibly lowest Coniacian, in Hokkaido, Japan.

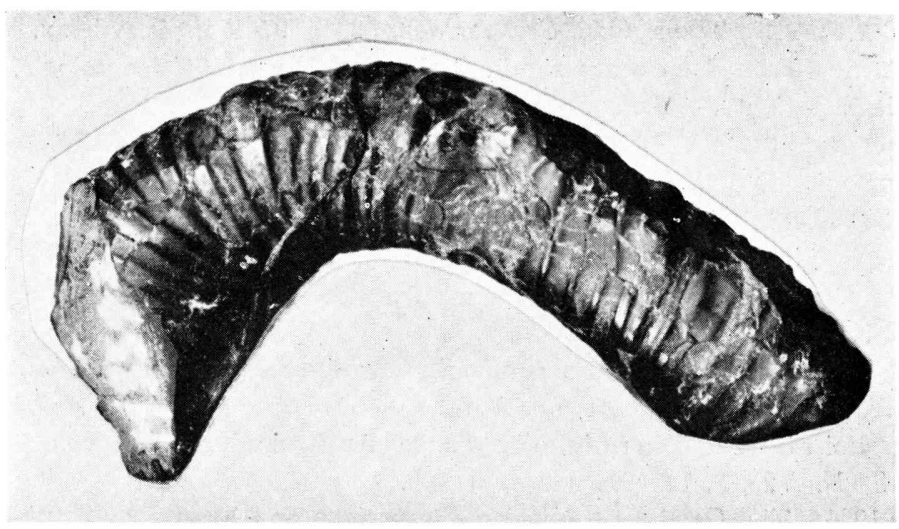

Fig. 22. Neocrioceras (?) sanushibense, sp. nov. Lateral view of a paratype (GK. H3542, T. M. coll.) from locality U238 (Nishihorobets), bed. Ur5 $\beta$, Urakawa area, Hidaka Province, Hokkaido. Natural size (T.M. photo.).

\section{Acknowledgements}

Our thanks are due to Professor Emeritus H. YABE for advice and access to his private collection, now preserved in the University of Tokyo, and to Professor T. Kobayashi of that University; to Mr. C. UEKI who kindly photographed for us the majority of the specimens figured in the plates; to Dr. W.N. EDwARDs, the Keeper of Geology, British Museum (Natural History), where one of us (T. M.) has been enabled to work by a British Council Scholarship, for facilities of that Museum; to Dr. L.F. Spath; and to Vicomtesse E. Basse de Mènorval and Général M. Collignon for information about certain ammonites from Syria and Madagascar.

\section{Works Cited}

Anderson, F. M. 1902. Cretaceous Deposits of the Pacific Coast. Proc. Calif. Acad. Sci., [3] 2, $1,1-154$, pls. i-xii.

- 1931. The genus Fagesia in the Upper Cretaceous of the Pacific Coast. Jour. Paleont., 5, 121-126, pls. 15-17.

Anderson, F. M. \& G. D. Hanna 1935. Cretaceous Geology of Lower California. Proc. Calif, Acad. Sci., [4] 23, 1, 1-34, pls. 1-11. 
BAsse, E. 1950. Quelques Mollusques du Crétacé de Colombie. Bull. Soc. Géol. France, [5] 20, 245-255, pl. xi.

Billinghurst, S. A. 1927. On some new Ammonoidea from the Chalk Rock. Geol. Mag., 44, 511-518, pl. xvi.

Boule, M., P. Lemoine \& A. Thévenin 1906. Paléontologie de Madagascar III-Céphalopodes crétacés des environs de Diego Suarez. Ann. Paléont., 1, 173-192 (1-20), pls. xiv-xx (i-vii).

Collignon, M. 1952. Ammonites Néocretacés du Ménabe [Madagascar] II-Les Pachydiscidae. Trav. Bur. Géol., Tananarive, no. 41, 114 pp., 33 pls.

Diener, C. 1925. Ammonoidea Neocretacea. Fossilium Catalogus I, Animalia, 29, 244 pp.

Dubourdieu, G. 1953. Ammonites Nouvelles des Monts du Mellegue. Bull. Serv. Carte Géol. Algérie, [1] 16, 76 pp., 4 pls.

FORBES, E. 1846. Report on the Fossil Invertebrata from Southern India, collected by Mr. KAYE and Mr. Cunliffe. Trans. Geol. Soc. London, [2] 7, 97-174, pls. vii-xix.

Grossouvre, A. de 1894. Recherches sur la Craie Supérieure II Paléontologie. Les Ammonites de la Craie Superieure. Mém. Carte géol. dét. France (1893), 264 pp., 39 pls.

HAYASAKA, I. \& A. FUKAYA, 1951. On the ontogeny of Barroisiceras minimum YABE from the Upper Ammonite Bed in Hokkaido. Jour. Fac. Sci., Hokkaido Univ., [4] 7, 324-330, pls. i-ii.

Hoteren, van E. C. N. 1921, Cretaceous Cephalopoda from Pondoland. Ann. Transvaal Museum, $8,1,1-48$, pls. i-xi.

Hyat, A. 1900. Cephalopoda in Zittel-Eastman, Text book of Paleontology. 2nd ed., 1, 502-604, London \& New York.

JACOB, G. 1908. Études sur quelques Ammonites du Crétacé moyen. Mém, Soc. géol. France, Paléont., 15, Mem. 38 (1907), 64 pp., 9 pls.

JIMBO, K. 1894. Beiträge zur Kenntniss der Fauna der Kreideformation von Hokkaido. Paläont. Abhandl., 6 (N. F. 2), 3, 149-194, pls. xvii-xxv.

Kobayashi, T. 1934. The Cambro-Ordovician Formations and Faunas of South Chosen. Palaeon. tology. Part I. Middle Ordovician Faunas. Jour. Fac. Sci., Imp. Univ. Tokyo, [2] 3, 8, 329519, pls. i-xliv.

Kossmat, F. 1895. Untersuchungen über die Südindische Kreideformation. Erster Theil. Beitr. Pal. Geol. Öst.-Ung. Or., 9, 97-203 (1-107), pls. xv-xxv (i-xi).

Marshall, P. 1926. The Upper Cretaceous Ammonites of New Zealand. Trans. N.Z. Inst., 56, 129-210, pls. 19-47.

Matsumoto, T. [MAтumoto] 1938a. A Biostratigraphic Study on the Cretaceous Deposits of the Naibuti Valley, South Karahuto. Proc. Imp. Acad. Japan, 14, 190-194.

- 1938b. Zelandites, a Genus of Cretaceous Ammonites. Japan. Jour. Geol. Geogr., 15, 137-148, pl. xiv.

- 1942a. A Note on the Japanese Cretaceous Ammonites Belonging to the Subfamily Desmoceratinae. Proc. Imp. Acad. Japan, 18, 24-29.

- 1942b-1943. Fundamentals in the Cretaceocs Stratigraphy of Japan. Part I. Mem. Fac. Sci., Kyushu Imp. Univ., [D] 1, 129-280, pls. v-xx (1942); Parts II \& III. ibid., 2, 97-237 (1943).

- 1942c. A Note on the Japanese Ammonites Belonging to the Gaudryceratidae. Proc. Imp. Acad. Japan, 18, 666-670.

- 1942d. A Note on the Japanese Ammonoid Species Belonging to the Tetragonitidae. ibid., 671-673.

- 1942e. A Short Note on the Japanese Cretaceous Phylloceratidae. ibid. 674-676.

- 1947. 日本産 Pachydiscinaeの概要, 九州大学理学部研究制告地筫学之部 2 叁 1 号: A Note on the Japanese Pachydiscinae. Rep. Dept. Geol., Fac. Sci. Kyushu Univ., 2, 1, 34-46 (in Japanese)

- 1951. A Note on the Pachydiscinae, a Cretaceous Ammonite Group. Trans. Proc. Palaeont. Soc. Japan, N.S. 1, 19-26.

(Editor) 1954. The Crataceous Syștem in the Japanese Islands. (Compiled by the Cretaceous Research Committee) 324pp., 20 pls., Tokyo.

Matsumoto, T. \& R. Saito 1954. A nearly smooth Pachydiscid from Hokkaido, Japan. Japan. Jour. Geoi. Geogqr., 24, 87-92, pls. ix-xi. 
Pervinquitere, L. 1910. Sur quelques ammonites du crétacé Algérien. Mém. Soc. géol. France. Paléont., 17, Mem. 42. 86 pp., 7pls.

SALFELD, H. 1919. Über die Ausgestaltung der Lobenlinie bei Jura- und Kreideammonoideen, Nachr. K. Ges. Wiss. Göttingen, Math. Phys. Kl., 3, 449-467.

SCHLÜTER, C. 1871-6. Die Cephalopoden der oberen deutschen Kreide. Palaeontographica, 21-24, 264pp., 55 pls, (21, 1-24, pls. i-viii, 1871; 25-120, pls. ix-xxxv, 1872; 24, 121-264, pls. xxxvi-lv, 1876).

ScHMidT, F. 1873. Über die Petrefacten der Kreideformation von der Insel Sachalin. Mem. Acad. Imp. Sci., St. Petersbourg, [7] 19, 3, 1-37, pls. i-viii.

SHIMizU, S. 1926. Three interesting Cretaceous Ammonites recently acquired from Hokkaido and Saghalin. Proc. Imp. Acad. Japan, 2, 547-550.

- 1929. Cretaceous Deposits of North and South Saghalin; a Comparison. Ann. Rep. Saito Ho.on Kai, 5, 30-43.

- 1932. On a new type of Senonian Ammonites, Pseudobarroisiceras nagaoi SHIMIzU gen. et sp. nov. from Teshio Province, Hokkaido. Japan. Jour. Geol. Geogr.. 10, 1-4. pl, i,

- 1933. Note on Two Interesting Senonian Ammonites from Hokkaido and South Saghalin, Jour. Shanghai Sci. Inst., [II] 1, 11-15. pl. ii.

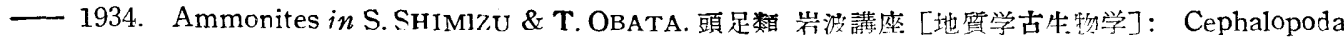
in IWANAMl's Lecture Series of Geology \& Palaenntolngv, 137 pp., Tokyn (in Japanese).

- 1935a. Remarks on Gaudryceras aeolum d'ORBIGNY and Gaudrvceras aeoliforme FALLOT from the Albian of France. Jour. Shanghai Sci. Inst., [II] 2, 155-158.

- 1935b. The Upper Cretaceous Cephalopods of Japn, Part I. ibid., 159-226.

- 1935c. The Upper Cretaceous Ammonites So-called Hamites in Japan. Proc. Imp. Acad. Japan, 11, 271-273.

SimionfescU, I. 1899. Fauna cretacica superiốra de la Ürmös (Transilvania), Acad. Românâ (Publ. Fondului Vasilie Adamachi), $4,38 \mathrm{pp} ., 3 \mathrm{pls}$.

Spath, L. F. 1921. On the Upper Cretaceous Ammonoidea from Pondoland, Ann. Durban Museum, 3, 39-57, pls. vi-vii.

- 1922. On the Senonian Ammonite Fauna of Pondoland. Trans. Roy. Soc. South Africa, 10, 3, 113-147. pls, v-ix.

- 1923. On the Ammonite Horizons of the Cault and Contiguous Deposits. Sum. Progr. Geol. Surv., (1922), 139-149.

- 1925. Senonian Ammonoidea from Jamaica. Geol, Mag., 62, 28-32, pl. i.

- 1939. Problems of Ammonite Nomenclature. 7. The Genera Paraphyiloceras and Neophylloceras SHimizu. Geol. Mag., 76, 451-454.

- 1953. The Upper Cretaceous Cephalopod Fauna of Graham Land. Falkland Island Dependencies Surv., Sci. Rep.. 3, 60pp., 13pls.

Stephfnson, L. W, 1941. The larger Invertebrate Fossils of the Navarro Group of Texas, Univ. Texas Bull., 4101, 641 pp., 95 pls.

SToliczkA, F. 1863-65. Ammonitidae, with revision of the Nautilidae, \&c. in Bl.ANFord and StoliczKa (1861-65): The Fossil Cephalopoda of the Cretaceous Rocks of Southern India. Mem. Geol. Surv. India (Pal. Indica,), 216 pp., 94 pls.

Uhlig. V. 1؟07. Die Cephalopodenfauna der Wernsdorfer Schichten. Denkschr. K. Akad. Wiss., Wien. Math. Nat. Kl., 46, 127-290, pls. i-xxxii.

Wright, C. W. \& E. V. WRIGHT 1942. The Chalk of the Yorkshire Wolds. Proc. Geol. Assoc., 53, 112-127.

Y ABE, H. 1903-1904. Cretaceous Cephalopoda from Hokkaido. Jour. Coll. Sci. Imp. Univ. Tokyo, 18, 2, 1-55. pls. i-vii (Part I, 1903) ; 20, 2, 1-45, pls. i-vi (Part II, 1904).

- 1509. Zur Stratigraphie und Paläontologie der oberen Kreide von Hokkaido und Sachalin. Zeitschr. deutsch. geol. Ges., 61, 402-444.

- 1927. Cretaceous Stratigraphy of the Japanese Islands. Sci. Rep. Tohoku Imp. Univ., [2] 11, 27-100, pls. iii-ix. 
YABE, H. \& S. ShimizU 1925. Japanese Cretaceous Ammonites belonging to Prionotropidae. I. ibid., [2] 7, 125-138, pls. xxx-xxxiii.

1926. A Study on the Genus "Parapachydiscus" HyatT. Proc. Imp. Acad. Japan, 2, 171-173.

YoKoyama, M. 1890. Versteinerung aus der japanischen Kreide. Palaeontographica, 36, 159-202, pls. Xviii-Xxv. 
C. W. Wright and T. Matsumoto

Some Doubtful Cretaceous Ammonite Genera from Japan and Saghalien

\section{Explanation of Plates}




\section{Plate 7}

Fig. 1. Scalarites mihoensis, sp. nov. Upper view of immature holotype (GT. I-2951a, T. M. Coll.) from locality N27a, zone Mh4 in the Naibuchi Valley, South Saghalien.

Fig. 2. Scalarites mihoensis, sp. nov. A paratype (GT. I-3352, T. M. Coll.), a part of middle aged whorls from locality T848p, bed IId ( ), Abeshinai-Saku area, Teshio Province, Hokkaido.

Fig. 3. Scalarites scalaris (YABE). An example (GT. I-2931, T. M. Coll.) from locality N125dl, zone $\mathrm{Mh} 2$ in the Naibuchi Valley, South Saghalien, showing elliptical coiling in later whorls. $\times 2 / 3$.

Fig. 4. Ryugasella ryugasensis, sp. nov. Lateral(a), ventral (b) and dorso-lateral (c) views and cross section (d) of holotype (GT. I-2862, T.M. Coll.) from locality N18f, zone Rayl in the Naibuchi Valley, South Saghalien.

Fig. 5. Neocrioceras (?) sanushibensis, sp. nov. Lateral (a) and ventral (b) views of holotype (GT. I-342, H. YABE's Coll.) from locality 'B' of the Saushisanushibe, 'Pachydiscus Beds' (=Anapachydiscus zone) in the Iburi Province, Hokkaido.

Fig. 6. Pseudoxybeloceras quadrinodosum (JiMBo). Lateral (a) and ventral (b) views of a relatively well preserved example (GT. I-341, H. YABE's Coll.) from the Ikushumbets, upper course above the mouth of the Yoshiashi-zawa, 'Pachydiscus Beds' (=Anapachydiscus zone) in the Ishikari Province, Hokkaido.

All the figures are of natural size, unless otherwise stated. Photos by C. UEKI. 

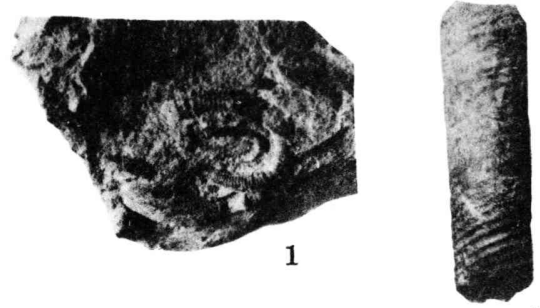

$4 a$

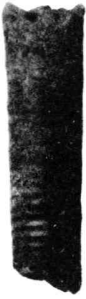

$4 b$

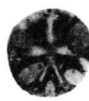

$4 d$

$4 c$
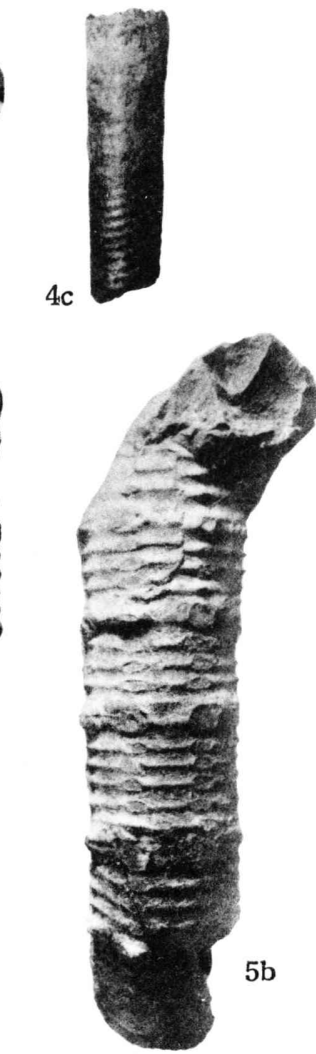
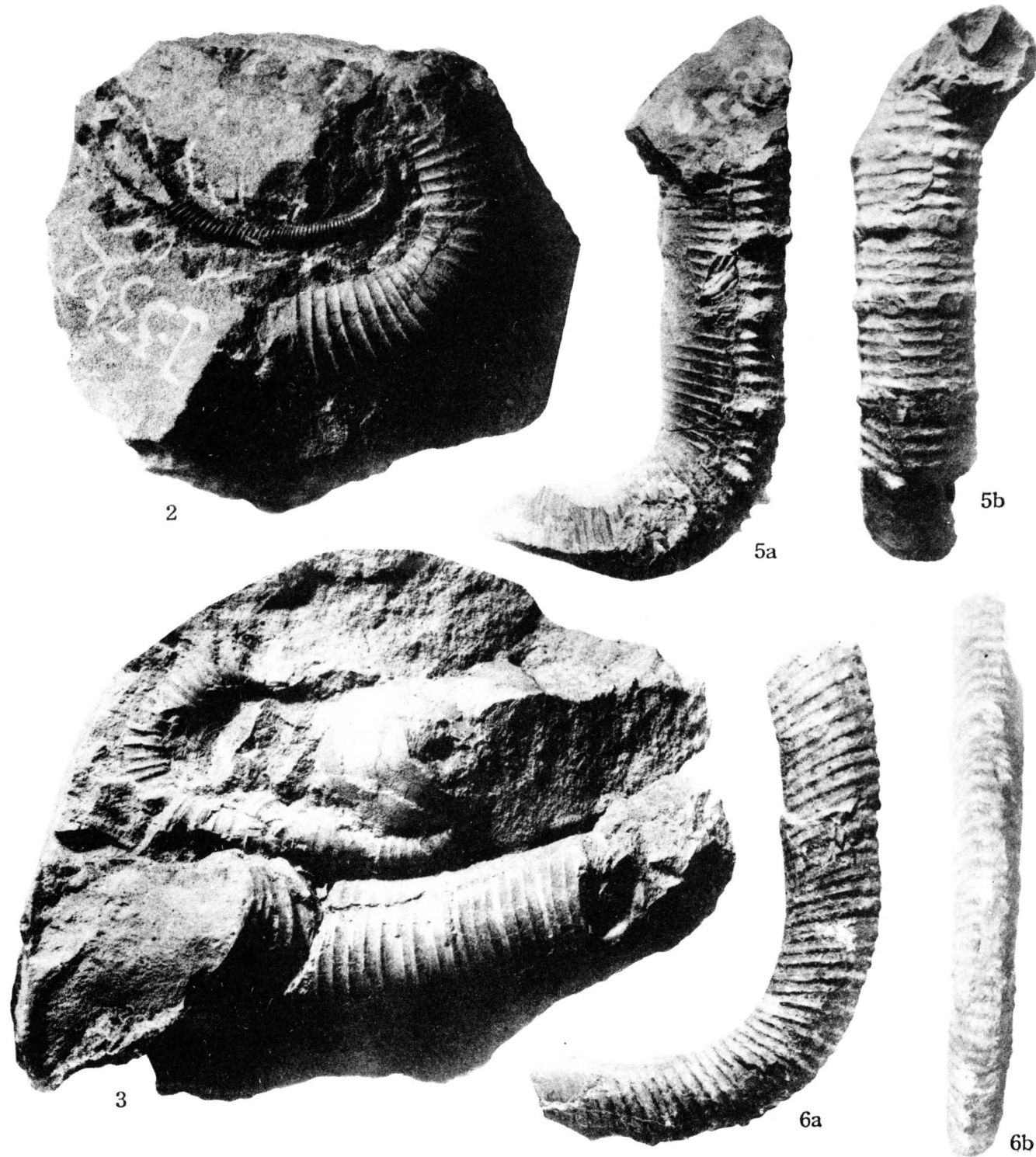


\section{Plate 8}

Fig. 1. Yokoyamaoceras kotoi (JiMBo). Apertural (a), lateral (b) and ventral (c) views of holotype (GT. I-107, illustrated by JiMBo, 1894, pl. v. fig. 2, 2a, 2b) from the Obirashibets Valley, about $60 \mathrm{~km}$. from its mouth in Teshio Province, Hokkaido.

Fig. 2. Eogunnarites unicus (YABE). Ventral (a) and two lateral $(b, c)$ views of a young example (GT. I-3245b, T.M. Coll.) from locality T608, bed IIb' in the Saku, a tributary of the Teshio, Teshio Province, Hokkaido.

Fig. 3. Eogunnarites unicus (YABE). Lateral (a) and frontal (b) views of a middle aged example, holotype (GT. I-255, illustrated by YABE, 1904, pl. vi, fig. 5a. b) from Kamitakambe, a right branch of the Ikushumbets near Poronai, Ishikari Province, Hokkaido.

Fig. 4. Eogunnarites unicus (YABE). Lateral (a) and ventral (b) views and cross-section (c) of another middle aged example (GT. I-3245a, T. M. Coll.) from locality T608, bed IIb in the Saku, a tributary of the Teshio, Teshio Province, Hokkaido.

Fig. 5. Eogunnarites unicus (YABE). Lateral (a) and ventral (b) views of a fragment of the last whorl (GK. H1556, T. M. Coll.) from locality Y259, bed IId in the Shiyubari Valley, Ishikari Province, Hokkaido.

All the figures are of natural size. Photos by C. Ueki (1-4) and T. MASTumoto (5). 


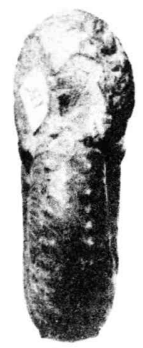

1a

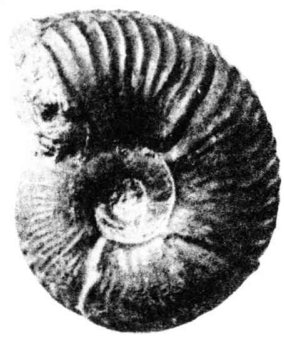

$1 b$

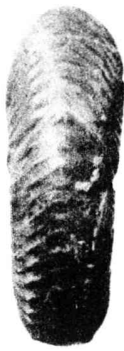

$1 c$



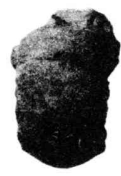

$2 a$

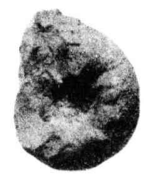

$2 \mathrm{~b}$



2c

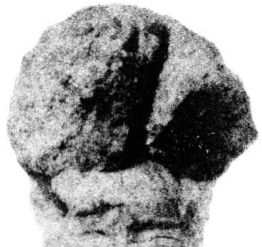



$4 a$
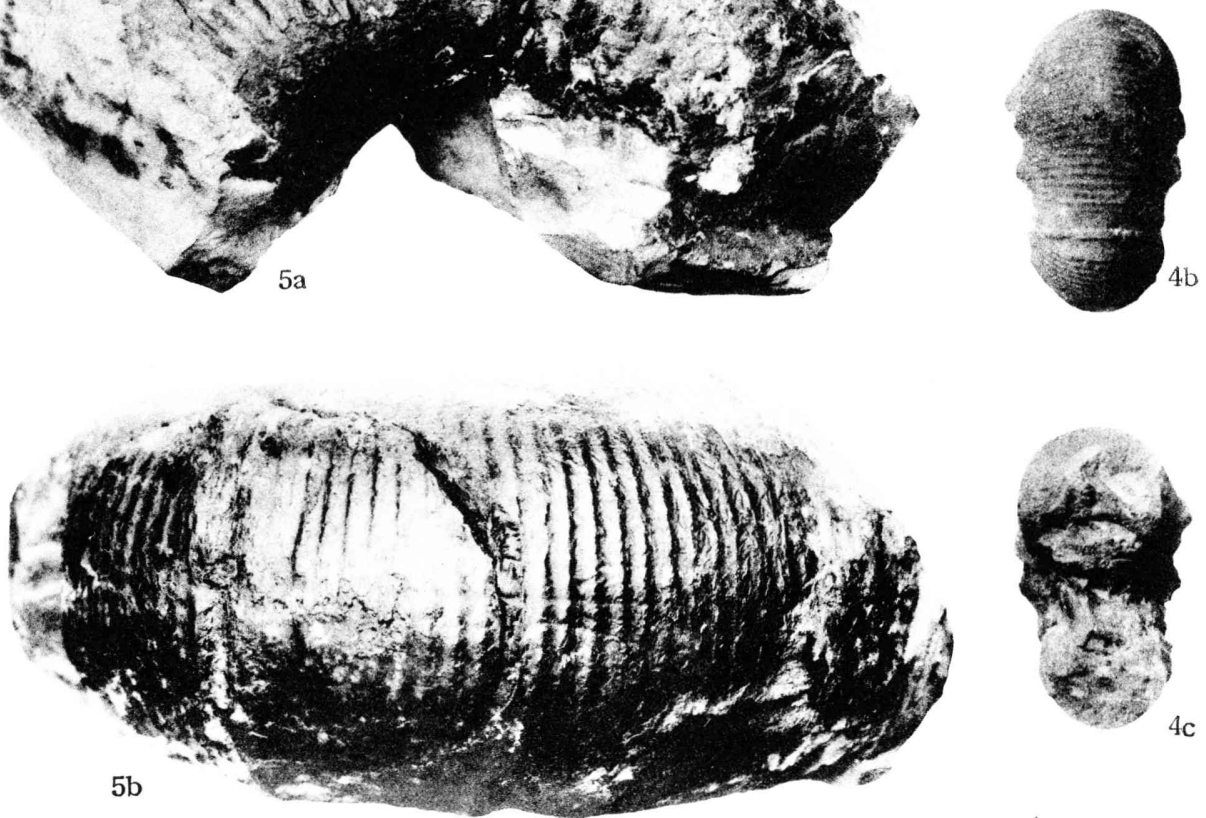